\title{
The Potential Usefulness of Several Insects and Fatty Acids in Allergic Disorders
}

\author{
Young Cheol Lee* \\ Department of Herbology, Sangji University, Republic of Korea
}

Received: 䟧January 18, 2019; Published: 畊January 25, 2019

*Corresponding author: Lee Young Cheol, Department of Herbology, Sangji University, Wonju 220-702, Republic of Korea

\begin{abstract}
Insects are the largest and widely distributed group of animals and contain high quality essential fatty acids, proteins and minerals. Insects, which relieves pain, can play a key role in anti-inflammatory responses by inhibiting inflammatory mediators and are used as a medicine for the treatment of inflammatory diseases. We hypothesized that potential insects and their main ingredients regulates airway inflammation and asthma and can be developed as therapeutic drugs for the treatment of asthma. In our review we try to show the potential usefulness of insects and fatty acids in searching for new therapeutic solutions for allergic diseases. We summaries the knowledge about properties of insect fatty acids to indicate usefulness of knowledge about insect fatty acids in drug design. The field of possible using of insect and their fatty acids delivered to therapy of various human allergic diseases is still not sufficiently investigated. Undoubtedly, more attention should be paid to insects and their fatty acids due to searching new therapeutic agents in allergic disorders.
\end{abstract}

Keywords: Insect; Fatty Acids; Allergic Diseases

\section{Introduction}

Insect medicine is an old ancient medicinal concept that is still used in Asia. It can be understood as the traditional animal species medicines, including the dried animal bodies, secretions and processing natural products of medicinal insects. Entomotherapy is the use of insects as medicines and is an important complementary and alternative to modern therapy in many parts of the world [1]. One of the most considerable differences in the drug materials in East Asian traditional and modern scientific medicines is the use of insects [2,3]. Nutritionally, insects are high in protein and fat compared with typical dietary items like fruit and vegetation. In small quantities, they may serve to provide important fatty acids. It is well known that insects are not only selected based on their environmental availability, but also their nutrient composition. Insects can play a key role (in anti-inflammatory responses by inhibiting (secreting) inflammatory mediators) in the diet of many nations. Their high nutritive value is mainly determined by a high content of protein, essential fatty acids, vitamins, minerals and other bioactive substances [4].

\section{Potential Usefulness of Fatty Acids}

As shown Table 1 [5-14], the major components of medicinal insects were myristic acid, oleic acid, palmitic acid and palmitoleic acid. There are many kinds of necessary amino acids and inorganic elements for mankind in insects. As shown Table 2 [15-33], oleic acid reduces IgE binding to allergens and decreases the production of inflammatory mediators by inhibition the endothelial expression of VCAM-1, E-selectin and ICAM-1. Linoleic acid reduces bronchoalveolar inflammatory cell count and lung IL-5 levels in an animal model. Also, it reduces proinflammatory cytokines production by eosinophils and bronchial epithelial cells. Palmitoleic acid promotes anti-inflammatory effects in macrophages exposed to LPS. However, palmitic acid sensitizes dendritic cells resulting in augmented secretion of Th1/Th17 cytokines upon proinflammatory stimulation. n-3 PUFA may directly regulate the function of the effector cells that mediate the allergic inflammatory response. Increased n-3 PUFA preferentially modulate the Th2-cell response, there was a marked down-regulation of IL-5, IL-9, IL-13 and RANTES n-3 PUFA suppress FceRI-mediated activation of mast cells. 
Table 1: Summary of major compounds (fatty acids) identified from several kinds of medicinal insects and their biological activities.

\begin{tabular}{|c|c|c|c|c|}
\hline $\begin{array}{l}\text { Herbs (Latin } \\
\text { Names) }\end{array}$ & Major chemical Compounds & Molecular Formula & Pharmacological Acitivities & References \\
\hline $\begin{array}{l}\text { Locusta Migratoria } \\
\text { (Grasshopper) }\end{array}$ & $\begin{array}{c}\text { Myristic acid } \\
\text { Palmitic acid } \\
\text { Palmitoleic acid } \\
\text { Stearic acid } \\
\text { Oleic acid } \\
\text { Linoleic acid } \\
\text { á-Linolenic acid }\end{array}$ & $\begin{array}{l}\mathrm{C}_{14} \mathrm{H}_{28} \mathrm{O}_{2} \\
\mathrm{C}_{16} \mathrm{H}_{32} \mathrm{O}_{2} \\
\mathrm{C}_{16} \mathrm{H}_{30} \mathrm{O}_{2} \\
\mathrm{C}_{18} \mathrm{H}_{36} \mathrm{O}_{2} \\
\mathrm{C}_{18} \mathrm{H}_{34} \mathrm{O}_{2} \\
\mathrm{C}_{18} \mathrm{H}_{32} \mathrm{O}_{2} \\
\mathrm{C}_{18} \mathrm{H}_{30} \mathrm{O}_{2}\end{array}$ & Anti-inflammation and analgesic effect & Clarkson C et al. [5] \\
\hline $\begin{array}{l}\text { Periostracum Cicadae } \\
\text { (the cast off skin } \\
\text { of Periostracum } \\
\text { Cicadae) }\end{array}$ & $\begin{array}{c} \\
\text { Alanine } \\
\text { Proline } \\
\text { Aspartic Acid } \\
\text { Serine } \\
\text { Threonine }\end{array}$ & $\begin{array}{l}\mathrm{C}_{3} \mathrm{H}_{7} \mathrm{NO} \\
\mathrm{C}_{5} \mathrm{H}_{9} \mathrm{NO}_{2} \\
\mathrm{C}_{4} \mathrm{H}_{7} \mathrm{NO}_{4} \\
\mathrm{C}_{3} \mathrm{H}_{7} \mathrm{NO}_{3} \\
\mathrm{C}_{4} \mathrm{H}_{9} \mathrm{NO}_{3}\end{array}$ & $\begin{array}{c}\text { - Anticonvulsant action } \\
\text { - Sedative action } \\
\text { - Analgesic action } \\
\text { - Antipyretic action } \\
\text { - Anti-allergic effects } \\
\text { - Decrease symptoms of Allergic Con- } \\
\text { tact Dermatitis } \\
\text { - Acne-remedy effects, antimicrobial } \\
\text { activity } \\
\text { - Improved the pathological changes } \\
\text { in rat kidney, reduce cholesterol and } \\
\text { proteinuria symptoms on MsPGN } \\
\text { rats, and its mechanism may be } \\
\text { related to inhibition of the over-ex- } \\
\text { pression of TGFâ1 } \\
\text { - Treatment of nonspecific anaphylactic } \\
\text { reactions. }\end{array}$ & $\begin{array}{c}\text { Zhonghua Bencao et al. } \\
\text { [6] } \\
\text { Gao X et al. [7] } \\
\text { Kim BNR et al. [8] } \\
\text { Lim JP et al. [9] } \\
\text { Wang Hh et al. [10] }\end{array}$ \\
\hline $\begin{array}{l}\text { Bombyx mory L. } \\
\text { (Original Silk Moth) }\end{array}$ & $\begin{array}{c}\text { Proline } \\
\text { Ornithine } \\
\text { Cystine } \\
\text { Niacin } \\
\text { Oleic acid } \\
\text { Palmitic acid } \\
\text { Linoleic acid } \\
\text { Stearic acid } \\
\text { Glutamic acid } \\
\text { Aspartic acid }\end{array}$ & $\begin{array}{c}\mathrm{C}_{5} \mathrm{H}_{9} \mathrm{NO}_{2} \\
\mathrm{C}_{5} \mathrm{H}_{12} \mathrm{~N}_{2} \mathrm{O}_{2} \\
\mathrm{C}_{6} \mathrm{H}_{12} \mathrm{~N}_{2} \mathrm{O}_{4} \mathrm{~S}_{2} \\
\mathrm{C}_{6} \mathrm{NH}_{5} \mathrm{O}_{2} \\
\mathrm{C}_{18} \mathrm{H}_{34} 0_{2} \\
\mathrm{C}_{16} \mathrm{H}_{32} \mathrm{O}_{2} \\
\mathrm{C}_{18} \mathrm{H}_{32} \mathrm{O}_{2} \\
\mathrm{C}_{18} \mathrm{H}_{36} \mathrm{O}_{2} \\
\mathrm{C}_{5} \mathrm{H}_{9} \mathrm{NO}_{4} \\
\mathrm{C}_{4} \mathrm{H}_{7} \mathrm{NO}_{4}\end{array}$ & $\begin{array}{c}\text { - DNA synthesis inhibiting action } \\
\text { Immunofacilitation }\end{array}$ & $\begin{array}{c}\text { Zhonghua Bencao, et } \\
\text { al. [6] }\end{array}$ \\
\hline $\begin{array}{l}\text { Holotrichia di- } \\
\text { omphalia } \\
\text { (Grub) }\end{array}$ & $\begin{array}{c}\text { Oleic acid } \\
\text { Palmitic acid } \\
\text { Palmitoleic acid } \\
\text { Holotricin } 2 \text { (basic protein and } \\
\text { has high contents of glycine } \\
\text { and proline residues.) }\end{array}$ & $\begin{array}{l}\mathrm{C}_{18} \mathrm{H}_{34} \mathrm{O}_{2} \\
\mathrm{C}_{16} \mathrm{H}_{32} \mathrm{O}_{2} \\
\mathrm{C}_{16} \mathrm{H}_{30} \mathrm{O}_{2}\end{array}$ & $\begin{array}{l}\text { - Anti-inflammation and analgesic effect } \\
\text { - Antibacterial effect } \\
\text { Immunomodulating effect on macro- } \\
\text { phage secretory and cellular activities }\end{array}$ & $\begin{array}{l}\text { Pei K et al. [12] } \\
\text { Lee SY et al. [13] } \\
\text { Kang NS et al. [14] }\end{array}$ \\
\hline
\end{tabular}


Table 2: Summary of major fatty acids and their biological activities in the development of lung diseases like asthma or COPD.

\begin{tabular}{|c|c|c|c|}
\hline $\begin{array}{l}\text { Fatty Acids \& } \\
\text { Mixture of Fatty Acids }\end{array}$ & Molecular Formula & Pharmacological Activities \& Key Findings & References \\
\hline Oleic acid & $\mathrm{C}_{18} \mathrm{H}_{34} \mathrm{O}_{2}$ & $\begin{array}{l}\text { Reduces IgE binding to allergens } \\
\text { Anti-inflammatory effect } \\
\text { 10-nitro-oleic acid blocked phosphorylation and degradation } \\
\text { of IkB and enhanced inhibitory binding of PPAR } \gamma \text { to NF-kB } \\
\text { Oral administration of oleic acid decreases the production of } \\
\text { inflammatory mediators (IL-1 } \beta \text {, IL-6) by Rat macrophages } \\
\text { Inhibits the endothelial expression of VCAM-1, E-selectin and } \\
\text { ICAM-1 }\end{array}$ & $\begin{array}{l}\text { Chung SY et al. [15] } \\
\text { Carrillo C et al. [16] } \\
\text { Reddy AT et al. [17] } \\
\text { Magdalon J et al. [18] } \\
\text { Carluccio MA et al. [19] }\end{array}$ \\
\hline Linoleic acid & $\mathrm{C}_{18} \mathrm{H}_{32} \mathrm{O}_{2}$ & $\begin{array}{l}\text { Reduce broncho-alveaolar inflammatory cell count and lung } \\
\text { IL-5 levels in an animal model of allergic asthma through } \\
\text { a PPARy-dependent mechanism } \\
\text { Reduce pro-inflammatory cytokines production by eosino- } \\
\text { phils and bronchial epithelial cells } \\
\text { Decrease ex vivo IL-4 production in splenocytes } \\
\text { Reduce allergen-induced IgE levels } \\
\text { Conjugated linoleic and vaccenic acids suppresses inflam- } \\
\text { mation and changes to the airways in an animal model of } \\
\text { allergic airway disease } \\
\text { Anti-inflammatory effects in allergic subjects with birch } \\
\text { pollen allergy }\end{array}$ & $\begin{array}{l}\text { Jaudszus A et al. [20] } \\
\text { Jaudszus A et al. [21] } \\
\text { Kelley DS et al. [22] } \\
\text { Yamasaki M et al. [23] } \\
\text { Kanwar RK et al. [24] } \\
\text { Turpeinen AM, et al. } \\
\text { [25] }\end{array}$ \\
\hline Palmitoleic acid & $\mathrm{C}_{16} \mathrm{H}_{30} \mathrm{O}_{2}$ & $\begin{array}{l}\text { Promotes anti-inflammatory effects in macrophages exposed } \\
\text { to LPS through inhibition of inflammasome pathway } \\
\text { Negatively associated with percentage predicted FEV1 and } \\
\text { FVC }\end{array}$ & $\begin{array}{l}\text { Souza CO, et al. [26] } \\
\text { Kompauer I, et al. [27] }\end{array}$ \\
\hline Palmitic acid & $\mathrm{C}_{16} \mathrm{H}_{32} \mathrm{O}_{2}$ & $\begin{array}{l}\text { Palmitic acid sensitizes DCs resulting in augmented secretion } \\
\text { of TH1/TH17-instructive cytokines upon pro-inflammato- } \\
\text { ry stimulation } \\
\text { Induced MCP-1 and augmented LPS-primed production of } \\
\text { IL-1 } \beta \text { and TNF- } \alpha \text { in macrophages } \\
\text { \& Increased the number of lung macrophages and augmented } \\
\text { high fat diet-induced neutrophilic airway inflammation in } \\
\text { a high fat diet mouse model }\end{array}$ & 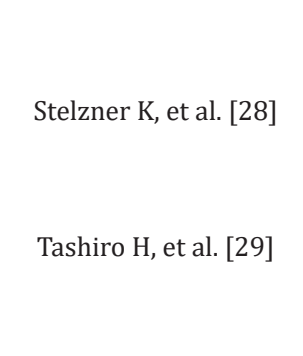 \\
\hline $\begin{array}{l}\text { Docosahexaenoic acid } \\
\qquad \text { (DHA) }\end{array}$ & $\mathrm{C}_{22} \mathrm{H}_{32} \mathrm{O}_{2}$ & $\begin{array}{l}\text { Positively associated with FEV1 (\% predicted) and FVC (\% } \\
\text { predicted) }\end{array}$ & Kompauer I, et al. [27] \\
\hline $\begin{array}{l}\text { Eicosapentaenoic acid } \\
\qquad(\mathrm{EPA})\end{array}$ & $\mathrm{C}_{20} \mathrm{H}_{30} \mathrm{O}_{2}$ & $\begin{array}{l}\text { Dietary intake of EPA (and DHA) was even positively associat- } \\
\text { ed with asthma in a case-control study } \\
\text { Eicosanoids derived from the n-3 fatty acid EPA down-regu- } \\
\text { late the production of PGE2 }\end{array}$ & $\begin{array}{l}\text { Broadfield EC, et al. [30] } \\
\text { Kankaanpää P, et al. [31] }\end{array}$ \\
\hline
\end{tabular}




\begin{tabular}{|c|c|c|c|}
\hline $\begin{array}{c}\text { Mixture of fatty acids (1) } \\
\text { n-3 PUFA }\end{array}$ & $\mathrm{C}_{20} \mathrm{H}_{30} \mathrm{O}_{2}(\mathrm{EPA})$ & $\begin{array}{c}\text { n-3 PUFA may directly regulate the function of the effector } \\
\text { cells that mediate the allergic inflammatory response } \\
\text { Increased n-3 PUFA preferentially modulate the Th2-cell } \\
\text { response, there was a marked down-regulation of IL-5, IL-9, } \\
\text { IL-13 and RANTES }\end{array}$ & Bilal S, et al. [32] \\
$\begin{array}{c}\text { (EPA, DHA are the main active } \\
\text { forms of n-3 PUFA) }\end{array}$ & $\begin{array}{c}\mathrm{C}_{22} \mathrm{H}_{32} \mathrm{O}_{2} \\
\text { (DHA) }\end{array}$ & W-3 PUFA suppress FcERI-mediated activation of mast cells & Wang X, et al. [33] \\
\hline
\end{tabular}

\section{Conclusion}

Therefore, above results provide evidence about the potential usefulness of the mixture of fatty acids from medicinal insects in allergic disorders. Overall, fatty acids have various roles in the way they affect the immune system and allergic responses and no single dietary fatty acid is suitable for treating allergic disorders. It is necessary to conduct more large scale studies with relevant animal models to arrive at meaningful recommendations for various fatty acid interventions for clinical usefulness. Further scientific research will be accomplished. This issue is and will be subject of work of many researchers from different areas.

\section{Acknowledgment}

This work was supported by the National Research Foundation of Korea (NRF) grant funded by the Korea government (MSIT) (grant number 2016R1A2B4006269).

\section{References}

1. Seabrooks L, Hu L (2017) Insects: an underrepresented resource for the discovery of biologically active natural products. Acta Pharm Sin B 7(4): 409-426.

2. Pemberton RW (1999) Insects and other arthropods used as drugs in Korean traditional medicine. J Ethnopharmacol 65(3): 207-216.

3. Namba T, Ma YH, Inagaki K (1988) Insect-derived crude drugs in Chinese Song Dynasty. Journal of Ethnopharmacology 24(2-3): 247-285.

4. Mlcek J, Rop 0, Borkovcova M, Bednarova M (2014) A Comprehensive Look at the Possibilities of Edible Insects as Food in Europe Europe-a Review. Pol J Food Nutr Sci 64(3): 147-157.

5. Clarkson C, Mirosa M, Birch J (2018) Potential of Extracted Locusta Migratoria Protein Fractions as Value-Added Ingredients. Insects 9(1): 1-12.

6. Zhonghua Bencao (1999) Editorial Committee of National Administrative Bureau on Chinese Medicine Chinese Herbal Medicine. Shanghai Science and Technology Pub Co, Shanghai 9: 129-231.

7. Gao X, Hong L, Jia H, Li Wd, Xu Lp (2015) Study on anti-allergic effects and primary mechanism of ultrafine powder of Periostracum cicadae. Heilongjiang Animal Science and Veterinary Medicine 12: 22-25.

8. Kim BNR, Chae JW (2015) Effects of Cicadae Periostracum (CP) in Allergic Contact Dermatitis (ACD) Induced by DNCB in Mice. J Pediatr Korean Med 29: 1-15.

9. Lim JP (2010) Acne-remedy Effects of Extract Mixture of Pulsatillae Radix and Cicadidae Periostracum. Korean J Oriental Physiology \& Pathology 24(4): 653-660.

10. Wang Hh, Bao H, Yu Js, Lu H, Zhao Zq (2012) Experimental Study of Periostracum Cicadae and Bombyx Batryticatusin the Treatment of
Mesangial Proliferative Glomerulonephritis of Rats. Progress in Modern Biomedicine 12: 2814-2818.

11. Shin TY, Park JH, Kim HM (1999) Effect of Cryptotympana atrata extract on compound 48/80-induced anaphylactic reactions. J Ethnopharmacol 66(3): 319-325.

12. Pei K, Cao W, Guo QQ Xie YH, He ZM, et al. (2012) Analysis of liposoluble constituents in Holotrichia diomphalia by GC-MS and investigation their anti-inflammatory and analgesic activities. Journal of Chinese medicinal materials 35(3): 357-360.

13. Lee SY, Moon HJ, Kurata S, Kurama T, Natori S, et al. (1994) Purification and molecular cloning of cDNA for an inducible antibacterial protein of larvae of a coleopteran insect, Holotrichia diomphalia. J Biochem 115(1): 82-86.

14. Kang NS, Park SY, Lee KR, Lee SM, Lee BG, et al. (2002) Modulation of macrophage function activity by ethanolic extract of larvae of Holotrichia diomphalia. Ethnopharmacol 79(1): 89-94.

15. Chung SY, Mattison CP, Reed S, Wasserman RL, Desormeaux WA (2015) Treatment with oleic acid reduces IgE binding to peanut and cashew allergens. Food Chem 180: 295-300.

16. Carrillo C, Cavia Mdel M, Alonso Torre S (2012) Role of oleic acid in immune system; mechanism of action; a review. Nutr Hosp 27(4): 978990.

17. Reddy AT, Lakshmi SP, DornadulaS, PinniS, Rampa DR, et al. (2013) The nitrated fatty acid 10-nitro oleate attenuates allergic airway disease. J Immunol 191(5): 2053-2063.

18. Magdalon J, Vinolo MA, Rodrigues HG, Paschoal VA, Torres RP, et al. (2012) Oral administration of oleic or linoleic acids modulates the production of inflammatorymediators by rat macrophages. Lipids 47(8): 803-812.

19. Carluccio MA, Massaro M, Bonfrate C, Siculella L, Maffia M, et al. (1999) Oleic acid inhibits endothelial activation: A direct vascular antiatherogenic mechanism of a nutritional component in the mediterranean diet. Arterioscler Thromb Vasc Biol 19(2): 220-228.

20. Jaudszus A, Krokowski M, Möckel P, Darcan Y, Avagyan A, et al. (2008) HamelmannE.Cis-9, trans-11 conjugated linoleic acid inhibits allergic sensitization and airway inflammation via a PPARgamma-related mechanism in mice. J Nutr 138(7): 1336-1342.

21. Jaudszus A, Foerster M, Kroegel C, Wolf I, Jahreis G (2005) Cis-9, trans11-CLA exerts anti-inflammatory effects in human bronchial epithelial cells and eosinophils: comparison to trans-10, cis-12-CLA and to linoleic acid. Biochim Biophys Acta 1737(2-3): 111-118.

22. Kelley DS, Warren JM, Simon VA, Bartolini G, Mackey BE, et al. (2002) Similar effects of $\mathrm{c} 9$, t11-CLA and t10, c12-CLA on immune cell functions in mice. Lipids 37(7): 725-728.

23. Yamasaki M, Chujo H, Hirao A, Koyanagi N, Okamoto T, et al. (2003) Immunoglobulin and cytokine production from spleen lymphocytes is modulated in C57BL/6J mice by dietary cis- 9 , trans- 11 and trans-10, cis12 conjugated linoleic acid. J Nutr 133(3): 784-788. 
24. Kanwar RK, Macgibbon AK, Black PN, Kanwar JR, Rowan A, et al. (2008) Bovine milk fat enriched in conjugated linoleic and vaccenic acids attenuates allergic airwaydisease in mice. Clin Exp Allergy 38(1): 208218.

25. Turpeinen AM, Ylönen N, von Willebrand E, BasuS, Aro A (2008) Immunological and metabolic effects of cis-9, trans-11-conjugated linoleic acid in subjects with birch pollen allergy. Br J Nutr 100(1): 112 119.

26. Souza CO, Teixeira AA, BiondoLA, SilveiraLS, Calder PC, et al. (2017) Palmitoleic acid reduces the inflammation in LPS-stimulated macrophages by inhibition of $\mathrm{NF \kappa B}$, independently of PPARs. Clin Exp Pharmacol Physiol 44(5): 566-575.

27. Kompauer I, Demmelmair H, Koletzko B, Bolte G, Linseisen J, et al. (2008) Association of fatty acids in serum phospholipids with lung function and bronchial hyperresponsiveness in adults. Eur J Epidemiol 23(3): 175190.

28. Stelzner K, Herbert D, Popkova Y, Lorz A, Schiller J, et al. (2016) Free fatty acids sensitize dendritic cells to amplify TH1/TH17-immune responses. Eur J Immunol 46(8): 2043-2053.

ISSN: 2574-1241

DOI: 10.26717/BJSTR.2019.13.002434

Lee Young Cheol. Biomed J Sci \& Tech Res

(c) (i) This work is licensed under Creative

Submission Link: https://biomedres.us/submit-manuscript.php
29. Tashiro H, Takahashi K, SadamatsuH, Kato G, KurataK, et al. (2017) Saturated Fatty Acid Increases Lung Macrophages and Augments House Dust Mite-Induced Airway Inflammation in Mice Fed with High-Fat Diet. Inflammation 40(3): 1072-1086

30. Broadfield EC, McKeever TM, Whitehurst A, Lewis SA, Lawson N, et al. (2004) A casecontrol study of dietary and erythrocyte membrane fatty acids in asthma. Clin Exp Allergy 34(8): 1232-1236.

31. Kankaanpää P, Sütas Y, Salminen S, Lichtenstein A, Isolauri E (1999) Dietary fatty acids and allergy. Ann Med 31(4): 282-287.

32. Bilal S, Haworth O, Wu L, Weylandt KH, Levy BD, et al. (2011) Fat-1 transgenic mice with elevated omega- 3 fatty acids are protected from allergic airway responses. Biochim Biophys Acta 1812(9): 1164-1169.

33. Wang X, Ma DW, Kang JX, Kulka M (2015) n-3 Polyunsaturated fatty acids inhibit Fc $\varepsilon$ receptor I-mediated mast cell activation. J Nutr Biochem 26(12): 1580-1588.

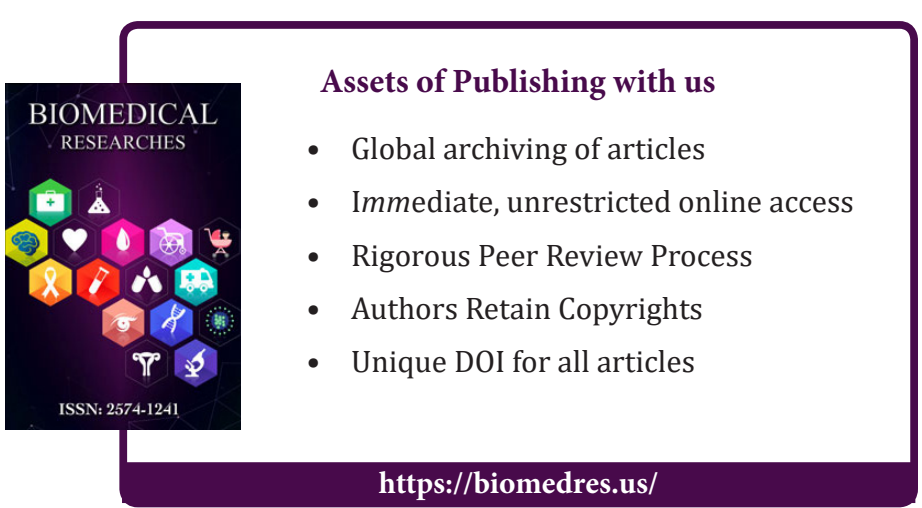

